\title{
The Model Design of the Nutrition Management Education and Training for Productive Age Women in UNNES
}

\author{
Atiek Zahrulianingdyah ${ }^{1}$, Rasita Purba ${ }^{2}$, Widya Karmila Sari Achmad ${ }^{3}$, Meddiati Fajri Putri ${ }^{4}$ \\ \{atiekzain_unnes@mail.unnes.ac.id ${ }^{1}$ \} \\ ${ }^{1,2}$ Department of Home Science Faculty of Engineering UNNES, Indonesia \\ ${ }^{3,4}$ Department of Home Science Faculty of Education UNM, Indonesia
}

\begin{abstract}
The eating habit in women of reproductive age can lead to a variety of negative effects caused by anaemia, malnutrition, lack of protein calories. In addition, it leads to a decrease in maternal health that also affects the conceived or breastfed child. The purpose of this study is to describe and analyse the knowledge of foodstuffs, nutritional knowledge, knowledge about anaemia, knowledge of food processing technique, knowledge of menu and diet in the family, the eating habit and the anaemia condition. Productive age mothers who live in the Banaran village, Gunungpati were sampled. The data were collected using documentation, structured interviews, food recall and haemoglobin test. The data were analysed using description percentage. The results showed that the percentage of the foodstuffs knowledge was $55 \%$ and was categorized as good category, $37.5 \%$ was categorized as moderate; the nutritional knowledge, $87.5 \%$ was in good category, $12.5 \%$ was in moderate category; the knowledge of anaemia, $57.5 \%$ was in good category, $37.5 \%$ was in moderate category, the food processing technique knowledge, $35 \%$ was in good category, $45 \%$ was in moderate category, description of menu knowledge, $20 \%$ was in good category, $67,5 \%$ was in moderate category, the eating habit was simple and less varied, 66,66\% did not have anaemia, $33,33 \%$ had mild anaemia.
\end{abstract}

Keywords: model, nutrition, education

\section{Introduction}

Anaemia in Indonesia is still one of the four nutritional problems in Indonesia. The iron nutritional anaemia in women of reproductive age is positively correlated with high mortality rates in pregnant and underweight mothers and low birth weight infants (LBW). Anaemia is defined as the situation of decreased haemoglobin concentration in the blood caused by iron deficiency required for the formation of the haemoglobin. Haemoglobin is a red substance, present in the form of a solution in red blood cells, whose primary function is to transport oxygen to all parts of the body (Drummond, et al, 2004). Iron, folic acid, vitamins and other mineral elements are required for the formation of haemoglobin formed in the bone marrow. These nutrients come from animal foods (liver, meat, and egg yolks), plant - based food (green vegetables and staple foods, whole grains). In developing countries, the level of anaemia is determined by measuring haemoglobin or haematocrit level. The most common symptoms of anaemia are fatigue, pallor on the face, lips, tongue, palms and feet and nails, dizzy vision, drowsiness and lethargic, shortness of breath, frequent panting, heart pounding, difficult bowel movements, and headache. Signs and symptoms of iron-deficiency anaemia are usually unspecific and often unclear, such as pallor, fatigue, heart pounding, tachycardia, and 
shortness of breath, increased susceptibility to infection, certain behavioural abnormalities, intellectual performance and reduced performance at work.

The basic principle in the prevention of anaemia caused by iron deficiency is to ensure regular iron intake to meet the body's needs and to increase the iron content and bioavailability in the diet. There are four main approaches of anaemia prevention: provision of iron supplements, fortification of food ingredients commonly consumed with iron, nutritional education, horticultural-based approaches to improve the availability of iron bios in common foodstuffs.

Actually, government intervention has been conducted by distributing iron tablets and folic acid in women of childbearing age, especially in pregnant women. However, it has not succeeded significantly. When the iron tablet was stopped, then the number of anaemia increased again. The dominant cause of this case is the eating habit of the women at the childbearing age. The basic anaemia problem is caused by the erroneous eating habit that does not pay attention to the balance of nutrition on the menu. Therefore, the eating only meet the needs of hunger, regardless of the nutritional factors of food consumed. The erroneous eating habit which results in the occurrence of anaemia is caused by many factors such as economic factors, low levels of maternal education, gender discrimination, lack of knowledge and mother's nutritional skills as individuals responsible for the contribution of family food.

The current anaemia prevention conducted by the Central Java Provincial Health Office is performed by distributing nutrition improvement program with activities such as case selection and case tracking, supplementary food distribution and referring malnourished children under five to the health centre or Hospital. In addition, it also undertakes preventive efforts through the development of integrated health service post, Counselling and Nutrition Education for the community, Community Empowerment, Development of Food and Nutrition Alert System and other cross-sectorial efforts. However, the implementation of this program has not provided optimal results. Therefore, it has not been able to solve the problem of malnutrition in Central Java completely. The efforts to overcome the problem of malnutrition must be conducted more thoroughly, comprehensively and take into account all related factors and supported by high commitment from Central Government and Local Government. Prevention efforts should also be able to encourage and accommodate the growing participation and active role of the community empowerment organizations, including universities, NGOs, CBOs matter Nutrition, Private, etc. Budihardja ( 2005) .

The pattern of food consumption is basically a form of application of eating habits. Foster and Anderson (2006: 131) argue that efforts to change eating habits are the most change resistant element. According to Berg (1986: 73), eating habit is formed within a person caused by the socialization process from the environment, including cognitive, affective and psychomotor aspects. Bloom's taxonomic theory confirms that there are three behavioural areas that can be observed as a result of counselling activities:

1) The cognitive region, starting from the level of knowing, understanding, using, analysis, synthesis to the level of evaluation.

2) Affective area, starting from the level of receiving, giving, responding, assessing, organizing, up to the level of living.

3) Psychomotor area, starting from the ability to perceive, mental, physical and emotional readiness, guided response, mechanisms to complex outward response.

The outcomes of the education and counselling are expected to reach all three levels, because the ultimate goal of an education is the acquisition of knowledge, appreciation and application Graeff, et al, (1996: 138) corroborates that human behaviour is the result of experience and human interaction with the environment manifested in the form of knowledge, 
attitude and action. One's behaviour is one's reaction to stimuli that come from outside or from within himself. Suhardjo (2006: 128) confirms that eating habit is a cultural and social phenomenon that can give a picture of the behaviour of the values embraced by a person or a group of people. Factors influencing the selection of food according to Barasi (2007: 23) are (1) internal factors (individual) including appetite, aversion, preference, emotion, personality type, mood and stress; (2) external factors (social culture) including culture, religion, ethical decisions, economic factors, social norms, education and awareness about health, media and advertising. There are three ways of forming human behaviour; 1) behavioural conditioning by Pavlov, Thorndike , and Skinner, 2) insight by Kohler, and 3) by using model or example ( Al- Muhdhar, $2012: 9$ ).

Beard's (2000) study on the effectiveness and strategy of iron supplementation during pregnancy concluded that food fortification and dietary changes due to educational influences proved to be successful in developing countries. Guptill, et al, (1993) conducted an intervention study using a nutrition education program aimed at improving nutritional status with dietary changes introduced fortified weaning food. This study showed that on the post test, $57 \%$ of mothers had the proper knowledge, $48 \%$ had tried new recipes and $16.6 \%$ adopted new recipes. Wenche Barth Eide's research, Siri Damman and Unni Silkoset, with Elisabet Helsing and Arne Oshaug (2002) concluded: "Thus there is progress in nutrition accelerating this progress is promising and encouraged." Nutrition education is important to provide a proper understanding of nutrition problems. Similarly, Reha Demired et al. (2011) show that nutrition education is effective to improve nutritional knowledge of pregnant women. However, it is not effective enough to combat anaemia. Jalila El Ati, Pierre Lefeore, Chiraz Beji, Chiheb Ben Rayana, Sadok Gaigi and Francis Delpeuch (2008) suggest the need for a strategy to combine food, iron supplementation, nutrition education for the community and vulnerable groups and training of health workers. However, tackling anaemia requires a careful calculation on its factors to produce a proper strategy in dealing with anaemia. Sujata Ganguly et al. (2011) argued that the intervention of iron tablet supplementation had no difference before and after iron supplementation. As a consequence, it appears that nutrition education has a significant impact in shaping healthy behaviour.

One form of nutrition education is providing counseling to the community. As stated by Azwar, (2004: 24) health education is an educational activity carried out by spreading messages with the intention of fostering attention, understanding and awareness of individuals and the community will live a healthy life. According to Suhardjo (2006: 87), nutrition counseling is an educational approach to produce the behavior of individuals or communities that are needed in improving or maintaining good nutrition. The educative approach is defined as a series of activities carried out systematically, planned, directed, with active roles of individuals and groups to solve community problems taking into account socio-economic factors in the local culture.

This present study designs a conceptual model of nutrition education and training which refers to the management functions consisting of planning, organizing, moving, controlling and evaluation. Johanssen in Suminar (2012: 32) argues that effective model criteria are applicable, controllable, adaptable and communicable. Therefore, the integration of the five management functions into the nutrition education and training was performed to achieve the applicable, practical, and effective nutrition education and training model for women in productive age. 


\section{Research methods}

The population of this study consisted of 204 productive aged women who live in the village of Banaran, Gunungpati Semarang, with the consideration that they are in charge of food and nutrition intake in the family. The purposive random sampling was conducted in accordance with the purpose of the study which resulted in 41 respondents (20\%) became the sample of the study.

The data were collected using documentation method in this study to obtain these following data about the mothers of productive age in Banaran village, Gunungpati subdistrict, Semarang regency: the number of productive age mothers, mothers of productive age and the age of mothers at productive age who became the respondents. A structured interview was used to obtain these following data: the dietary knowledge, nutritional knowledge, knowledge of anaemia, food processing techniques, knowledge of the menu, and the dietary menu commonly consumed in the family at Banaran village. Food recall method was used to look at the eating habit of the productive age women in Banaran village for three consecutive days.

Measurement of Anaemia was conducted by measuring the levels of haemoglobin or haematocrit (Beard, 2000). The threshold of haemoglobin and haematocrit level according to WHO / UNICEF / UNU, (Soegianto 2007) can be seen on the following table:

Table 1. Threshold Level of Haemoglobin and Haematocrit

\begin{tabular}{|l|l|l|}
\hline Age group & Haemoglobin $(\mathrm{gr} / \mathrm{dl})$ & Haematocrit $(\%)$ \\
\hline 6 months - 5 years & 11.0 & 33.0 \\
5 years - 12 years & 11.5 & 34.0 \\
12 years - 13 years & 12.0 & 36.0 \\
Man & 13 & 39.0 \\
Women & & \\
Pregnant & 11.0 & 33.0 \\
Not pregnant & 12.0 & 36.0 \\
\hline
\end{tabular}

Source: WHO / UNICEF / UNU (Soegianto 2007)

To achieve a more practical description of the degree or seriousness in anaemia, the levels of haemoglobin in the blood are divided into levels as follows:

a. $\quad$ Mild anaemia with $\mathrm{Hb}=8-10 \mathrm{~g} / 100 \mathrm{cc}$

b. Medium anaemia with $\mathrm{Hb}=6-8 \mathrm{~g} / 100 \mathrm{cc}$

c. Severe anaemia with $\mathrm{Hb}=<6 \mathrm{~g} / 100 \mathrm{cc}$

In this study, the data were analysed by using percentage description analysis

Qualitative and quantitative descriptive analysis of percentages were used to reveal dietary knowledge, knowledge of food processing techniques, nutritional knowledge, knowledge of anaemia, and menu knowledge.

\section{Research Results and Discussion}

Banaran village is a village on the process of rapid development. The location of the Banaran village is on the Sekaran, Gunungpati sub - district becomes very strategic because Banaran village is the centre of education development with the existence of Universitas Negeri Semarang in this region. This rapid development has shown signs of development 
into a heterogeneous area of the city. This area is heavily populated by diverse population in terms of employment, education, and lifestyle, social, economic and cultural conditions. The availability of the existing facilities at Banaran village facilitates its community in fulfilling various necessities of life.

Banaran village has three primary state schools: SDN Sekaran 1, SDN Sekaran 2 and MI Sekaran. The majority of its inhabitants send their sons and daughters to these school. However, the village of Banaran does not have junior high school, high school, and vocational high school. After their children graduated from the primary school, most of the Banaran village inhabitants send their children to a religious boarding school in the village of Patemon. However, if parents cannot afford to pay for the tuition fee, they send their children to work to help their parents.

There are many food vendors at Banaran village. They sell both traditional and modern food. Therefore, the students and inhabitants of Banaran village who do not have much time to cook on their own choose to buy their food. Universitas Negeri Semarang is located at the Banaran village area. Despite the short distances, many inhabitants of Banaran village has yet sent their children to get proper education. One of the factors that affect this condition of public education at Banaran village the economic factor. The majority of Banaran village inhabitants work as factory workers, construction workers, cleaning service at Universitas Negeri Semarang and sell food at the street vendors around the campus of Universitas Negeri Semarang. The inhabitants of the Banaran village are not aware of the importance of education. From the data obtained in Banaran village, there are two sub - villages, the first sub - village consisted of six communities and the second sub - village consisted of eight communities. There are ninety six productive age mothers at the first sub - village and 104 productive age mothers at the second sub - village. The majority of the productive age women in the Banaran village are primary education graduates. In addition, some of them do not graduate from elementary school. There are $4.5 \%$ of mothers of productive age who do not go to school, $60 \%$ of elementary school graduates, $20 \%$ of junior high school graduates, $10 \%$ of senior high school graduates and $5.5 \%$ of the productive age mothers who have college diploma.

The foodstuffs knowledge of the productive age mothers in the village Banaran, Gunungpati subdistrict, Semarang is summarized as follows: the foodstuff knowledge of the twenty two women at the productive age were categorized as good $(55 \%)$, fifteen women were categorized as moderate $(37,5 \%)$, three women $(7.5 \%)$ were categorized as low. 
Chart 1. Knowledge of Foodstuff

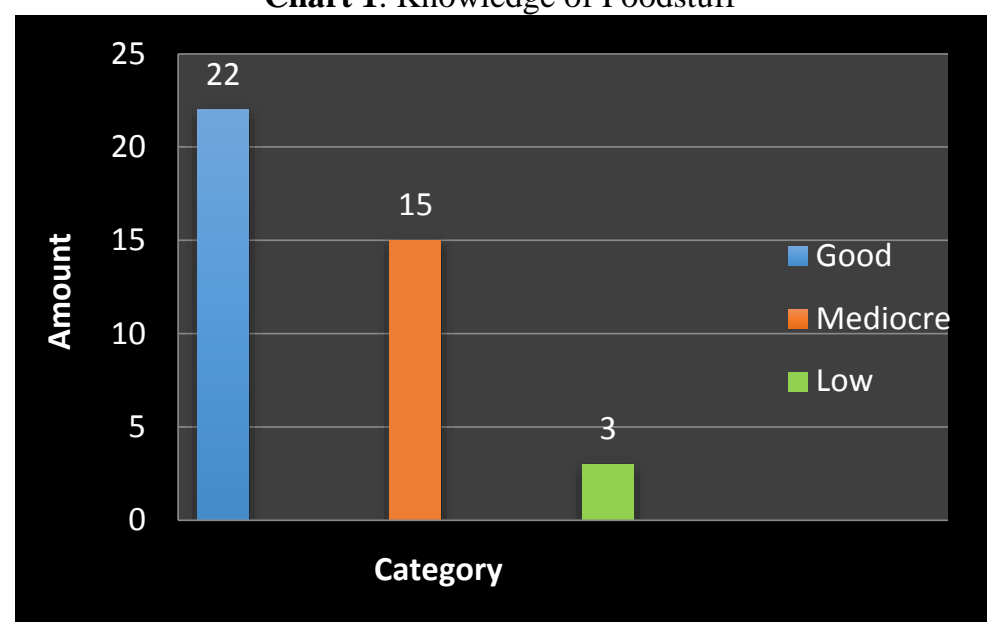

The results of the nutritional knowledge data analysis showed that thirty five mothers $(87$, $5 \%)$ were in good category and five mothers $(12,5 \%)$ were in moderate.

Chart 2. Nutritional Knowledge

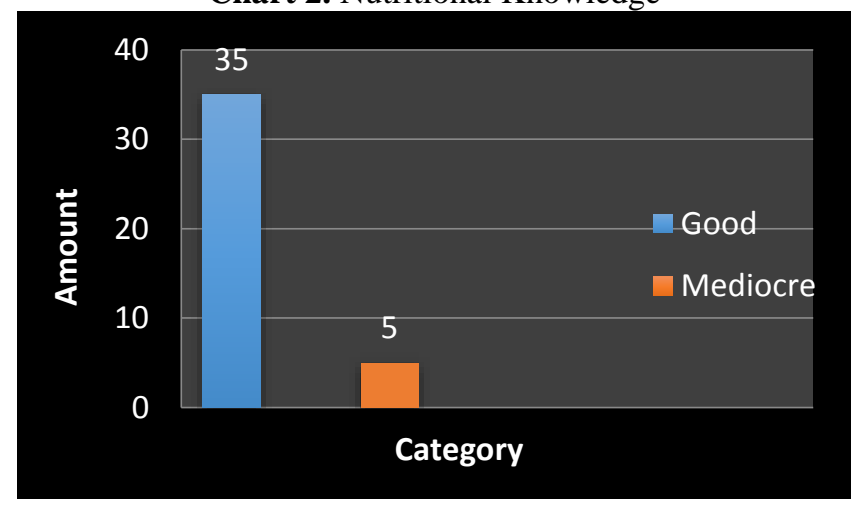

The results of analysis on the knowledge about anaemia showed that 23 mothers $(57.5 \%)$ were in good category, 15 mothers $(37.5 \%)$ were in moderate category, 2 mothers $(5 \%)$ were in the low category. 
Chart 3. Knowledge of Anaemia

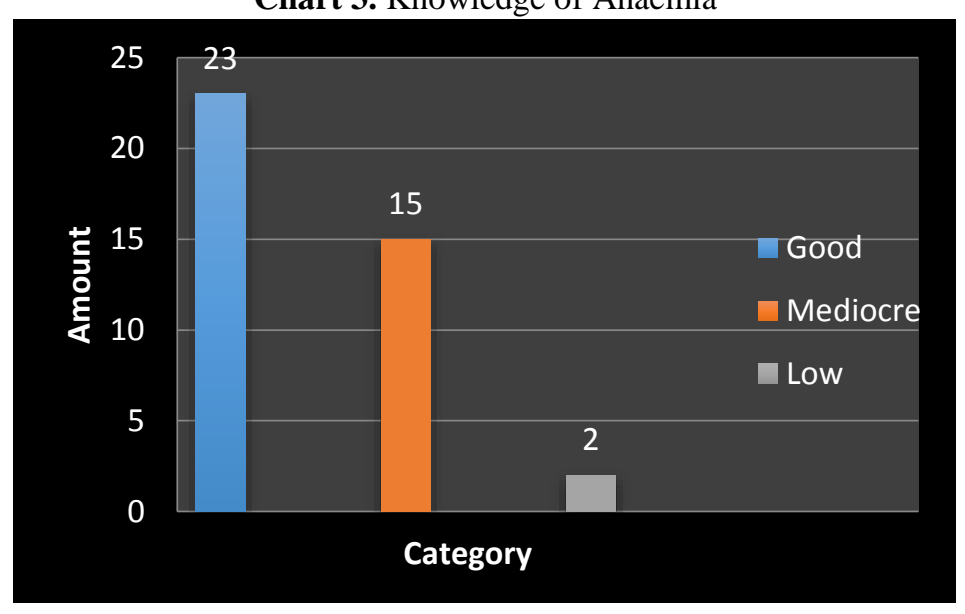

The results of data analysis on the knowledge of food processing technique showed that 14 mothers $(35 \%)$ were in good category, 18 mothers $(45 \%)$ were in moderate category and 8 mothers $(20 \%)$ in low category.

Chart 4. Knowledge of Food Processing Technique

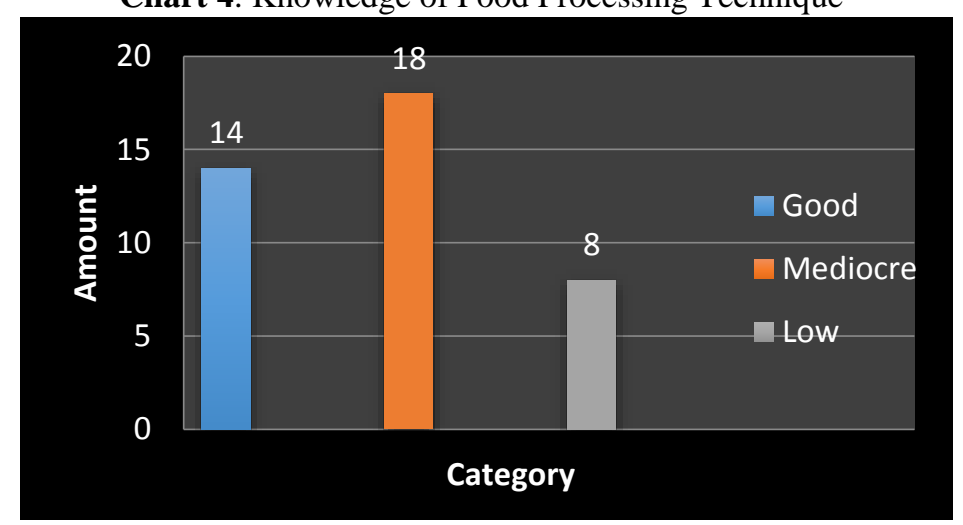

The result of data analysis on menu knowledge showed that 8 mothers (20\%) were in good category, 27 mothers $(67,5 \%)$ in moderate category and 5 mothers $(12,5 \%)$ in low category. 
Chart 5. Menu knowledge

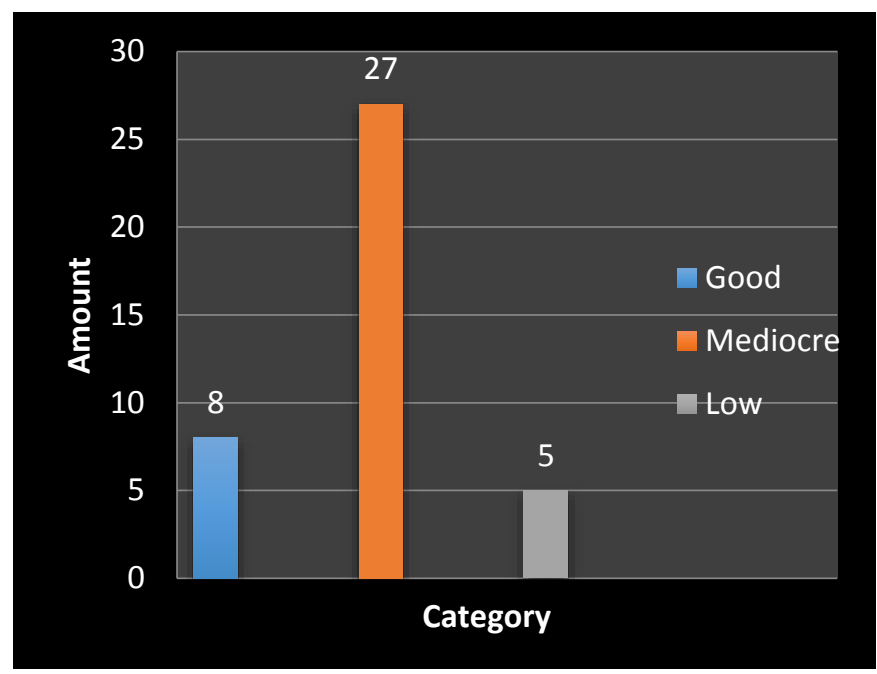

Based on the food recall for three days, qualitatively it can be described that poor eating habit does not harmonize with their nutritional knowledge. The diet has not been referring to the balanced nutrition menu. The results showed their nutritional knowledge is good, the dietary knowledge is about good, and the knowledge of menu is categorized as moderate. However, their eating habit received less attention. It seems that they used to buy ready-made food that was sold at food stalls around the campus, such as noodles, fried rice, friend chicken, fried soya, egg fried egg, soup vegetables. Based on the results of food recall for three days, their eating habit was poor and it did not reflect recommended in a balanced nutrition menu. This poor eating habit occurred because the mothers who worked sometimes did not have time to cook every day. Therefore, the family menu depended on the time owned by his mother and the financial condition. The menu is not suitable to the the daily nutritional needs. Similarly, the habit of consuming the fruit is limited to the fruits grown around their home such as rambutan, banana, and papaya. Their everyday beverage is generally plain water.

From the results of haemoglobin test, the anaemia condition experienced by productive age mothers in Banaran Village is as follows: 66, 66\% of the mothers were in normal condition, $33,33 \%$ of the mothers were in mild anaemia. Based on the results of this study, nutrition education and training for mothers of productive age must be conducted to solve the occurrence of anaemia. Based on the description of the results, a model of nutrition education and training is as follows: 


\section{Conceptual Model Design}

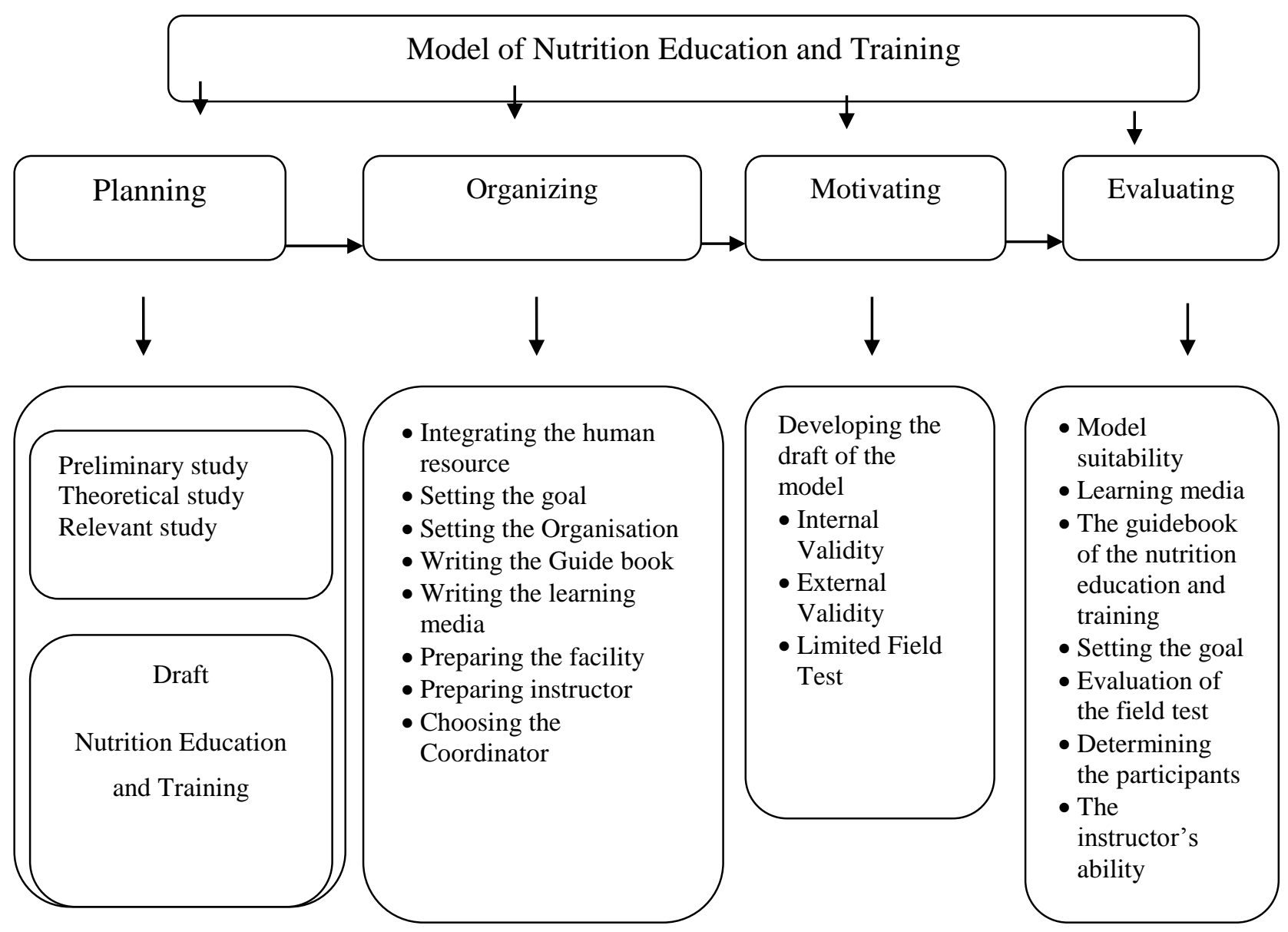

Figure 1. The Conceptual model of the nutrition education and training nutrition of productive age mothers in UNNES campus' surrounding to overcome anaemia

\section{CONCLUSION AND RECOMMENDATIONS}

Based on the results and discussion, it can be concluded that:

1. $55 \%$ of the productive age women had good food knowledge, $37,5 \%$ of the productive age women had moderate food knowledge.

2. $87.5 \%$ of the productive age women had good nutritional knowledge, $12.5 \%$ of the productive age women had in moderate nutritional knowledge.

3. $57,5 \%$ of the productive age women had the knowledge of anaemia, $37,5 \%$ of the productive age women had moderate the knowledge of anaemia. 
4. $35 \%$ of the productive age women had the good food processing technique knowledge, $45 \%$ of the productive age women had the moderate food processing technique knowledge.

5. $20 \%$ of the productive age women had the good menu knowledge, 67, $5 \%$ of the productive age women had the moderate menu knowledge.

6. The eating habit was poor and less varied referring to the balanced nutrition menu.

7. $6,66 \%$ of the productive age women did not have anemia, 33,33\% of the productive age women had mild anaemia.

8. The nutrition education and training must be conducted to overcome the occurrence of anaemia.

\section{Suggestion}

The suggestion is that nutrition education and training must be conducted so that mothers have the skills in preparing family menu and applying the balanced menu to have a healthy eating habit referring to the menu on balanced nutrition. A "Model" of nutrition education for productive mothers in Banaran village should be developed.

\section{BIBLIOGRAPHY}

Almatsier, Sunita. Soetardjo, Susirah. Soekarti Moesijanti. 2011. Balanced Nutrition In the Life Cycle. Jakarta: PT. Gramedia

Al-Muhdhar, MHI 2012. Student Understanding and Skills in Waste Management of Household and E-Media Implementation. Journal of Educational Science, 18 (1): 816.

Azwar, Azrul. 2004. Health and Nutrition Aspects in Food Security. Paper. in Proceeding Widyakarya National Food and Nutrition VIII. Jakarta: LIPI

Barasi, Mary E. 2009. At a Glance Nutrition Science. Jakarta: Erlangga Publisher.

Beard, JL. Gillespie, Stuart. 2000. Major Issues in the Control of Iron Difisiency The Micronutrien Initiative . New York: Unicef

Berg, A. 1986. The Role of Nutrition in National Development. Zahara D. Translation Noer. Jakarta: CV Rajawali .

Drummond, Karen Eich and Brefere Lisa M. 2004. Nutrition for Foodservice \& Culinary Profesionals. Published by John Wiley \& Sons, New Jersey: Inc., Hoboken.

Foster, GM and Anderson, BG 2006. Anthropology of Health. Translation.Jakarta: University of Indonesia Press. .

Graeff, Yudith A, John P.Elder, Elizabeth Mills Booth.1996. Communication for Communication and Change of Period.Mubasyir Hasanbasri's translation. Yogyakarta: Gajah Mada University Press.

Guire, Michelle Mc. And Beerman Kathy A. 2005. Nutritional Sciences, From Fundamentals To Food. Washington, DC: National Academies Press.

Guptill , Katharine S, Steven A. Esrey, Gbolah A, Oni and Kenneth Brown. 1993. Evaluation

Of A Face to Face Weaning Food Intervention In Kwara State, Nigeria Knowledge, Trial adm Adaption of A Home Prepared Weaning Food. Journa 1 Soc. Sci. Med. Vol. No. 5,36: 665-672

Reha Demired, Simoes, MC., Lawless, Jw., Latham, MC. 2011. Determination of Nutritional Training for the Prevention of Anemia On Pregnant Woment. Health and Nutrition Journal, Vol 51 
Sugiyono. 2009. Metode Penelitian Pendidikan, Pendekatan Kuantitatif, Kualitatif, dan R\&D. Bandung: Alfabeta

Suhardjo. 2006 . Various Ways of Nutrition Education. Jakarta: Earth Literacy

Vijayaraghavan Kamasamudram in Gibney, Michael J, Margetts Barrie M, Kearney John M, Arabic Lenore. 2009. The Public Health Nutrition (Public health Nutrition) Jakarta: Book Medical Publishers EGC

Wenche Barth Eide, Siri Damman and Unni Sil koset with Elisabet Helsing.2002. Journal Vol. 2, no 1.Training for Contemporary Understanding of Human Nutrition Condition 1 - Globalisation, Human Rights and Governance as dimensions of the study and practice of Public Nutrition in the 21 st Century-Experiences from recent educational Innovations at the University of Oslo.

Zahrulianingdyah, Atiek. 2013. Model Pengorganisasian Pendidikan \& Latihan (DIKLAT) Gizi Berbasis Masyarakat. Jurnal Ilmu Pendidikan, 19 (2) 129-135.

Zahrulianingdyah, Atiek. 2016. The Contribution of Indonesian Women's Eating Habit to Iron Deficiency Anemia. Pakistan Journal of Nutrition . DOI: 10.3923/pjn.2016

Zahrulianingdyah, Atiek; Triatma Bambang, . 2016. Pemberdayaan Masyarakat Marginal di Lingkungan Kampus UNNES dalam mengatasi Anemia. Penelitian. Semarang: LP2M UNNES 